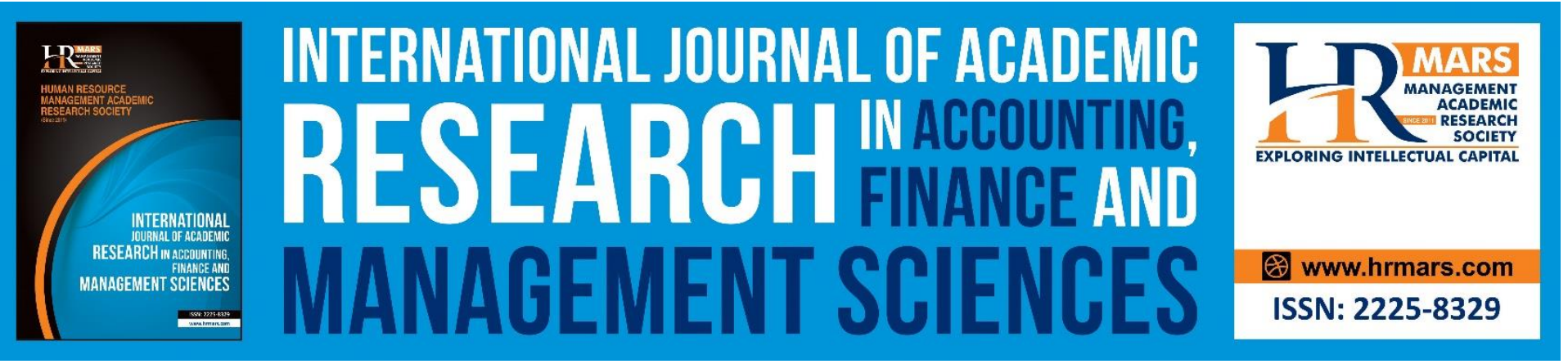

\title{
Multidimensional Deprivation Determinants among Lower Income Group Households in Selangor, Malaysia
}

\author{
Norhayah Zulkifli, Abul Bashar Bhuiyan, Tasnuba Haque
}

To Link this Article: http://dx.doi.org/10.6007/IJARAFMS/v11-i3/11957

DOI:10.6007/IJARAFMS /v11-i3/11957

Received: 10 July 2021, Revised: 15 August 2021, Accepted: 29 August 2021

Published Online: 18 September 2021

In-Text Citation: (Zulkifli et al., 2021)

To Cite this Article: Zulkifli, N., Bhuiyan, A. B., \& Haque, T. (2021). Multidimensional Deprivation Determinants among Lower Income Group Households in Selangor, Malaysia. International Journal of Academic Research in Accounting Finance and Management Sciences, 11(3), 848-836.

Copyright: (C) 2021 The Author(s)

Published by Human Resource Management Academic Research Society (www.hrmars.com)

This article is published under the Creative Commons Attribution (CC BY 4.0) license. Anyone may reproduce, distribute, translate and create derivative works of this article (for both commercial and non-commercial purposes), subject to full attribution to the original publication and authors. The full terms of this license may be seen at: $\underline{\text { http://creativecommons.org/licences/by/4.0/legalcode }}$

Vol. 11, No. 3, 2021, Pg. 848 - 836

http://hrmars.com/index.php/pages/detail/IJARAFMS

JOURNAL HOMEPAGE

Full Terms \& Conditions of access and use can be found at http://hrmars.com/index.php/pages/detail/publication-ethics 


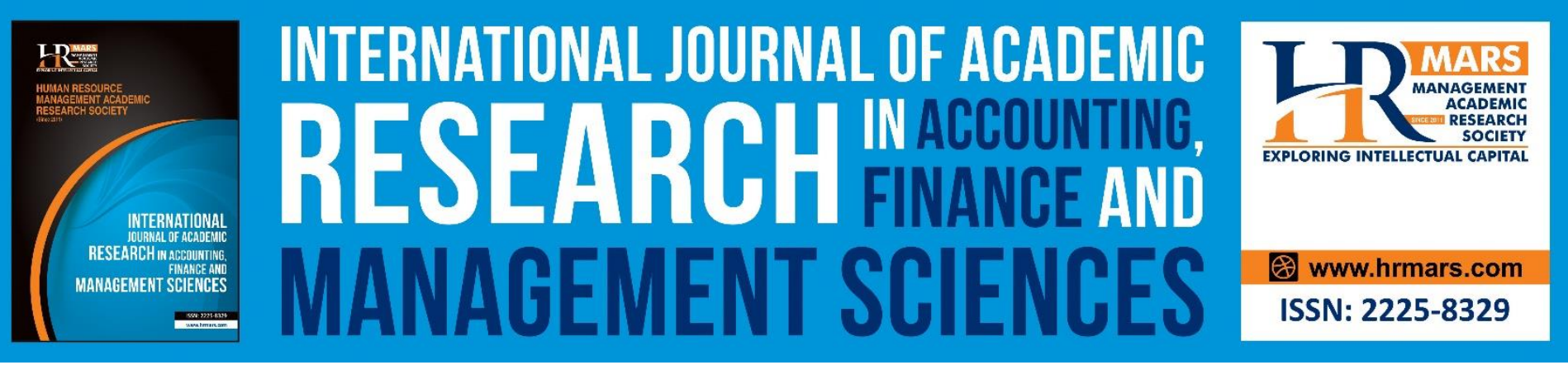

\title{
Multidimensional Deprivation Determinants among Lower Income Group Households in Selangor, Malaysia
}

\author{
Dr. Norhayah Zulkifli \\ Professor at Faculty of Business and Accountancy (FBA), University Selangor (Unisel), Shah Alam, \\ Malaysia \\ Email: norhayah@unisel.edu.my
}

\begin{abstract}
Dr. Abul Bashar Bhuiyan
Associate Professor at Faculty of Business and Accountancy (FBA), University Selangor (Unisel), Shah Alam, Malaysia

Email: norhayah@unisel.edu.my

Dr. Tasnuba Haque

Associate Professor at Faculty of Business and Accountancy (FBA), University Selangor (Unisel), Shah Alam, Malaysia

Email: haquebornee@gmail.com
\end{abstract}

\begin{abstract}
Poverty alleviation, socio-economic wellbeing, and sustainable livelihood of the stakeholders are among the prime initiatives of the 2030 shared prosperity vision of the Malaysian government. The agenda is part of the blueprint in the 2030 vision for the period of 2021 to 2030 to increase the income of all ethnic groups particularly the Bumiputeras comprising the lower-income group which is referred to as B40, the hard-core poor, the economically poor, those in economic transition, Orang Asli, Sabah, Sarawak Bumiputeras, the disabled, youths, women, children and senior citizens by 2030. Therefore, the present study investigates the current status and the influencing factors of multidimensional deprivation comprising health safety, education, and living standard among the lower-income group in Malaysia's wealthiest state, Selangor. The study adopts a quantitative approach in analysing the primary data from 404 samples of the B40 groups of the population that reside in Selangor nine districts. A purposive stratified random sampling method is used to select the respondents. Descriptive statistics, econometric techniques, Malaysian Human Poverty Index (MPHI) are utilised in the analysis. Based on Multidimensional Poverty Index (MPI) result, the study revealed that the overall incidence of deprivation to the access of basic education among the households was
\end{abstract}


INTERNATIONAL JOURNAL OF ACADEMIC RESEARCH IN ACCOUNTING, FINANCE AND MANAGEMENT SCIENCES

Vol. 11, No. 3, 2021, E-ISSN: 2225-8329 @ 2021 HRMARS

$1.26 \%$, access to basic healthcare deprivation was $1.95 \%$, and standard of living deprivation was $4.51 \%$ among the lower-income group in Selangor, Malaysia consequently. The study also checked the intensity of the deprivation gap within the above category of indicators and concluded that there is $2.51 \%$ still away from basic education access, $3.98 \%$ for basic healthcare, $36.14 \%$ of them are in the standard of living deprivation stage among the lower income group in Selangor, Malaysia. Finally, the present study summarized that overall Multidimensional Poverty Index (MPI) score whereas, there is 0.0029 or $.29 \%$ of the respondent are depriving together in the category of basic education, health, and standard of living among the lower income group in Selangor, Malaysia.

Keywords: Multidimensional Poverty Alleviation, B40 Income Group, Selangor, Malaysia

\section{Introduction}

Poverty alleviation, socio-economic wellbeing and sustainable livelihood of the stakeholders are among the prime initiatives of the Malaysian government (Chua \& Oh, 2011; Kronbak \& Vestergaard, 2011). The government has released its blueprint in the shared prosperity vision 2030 for the period 2021 to 2030 with an aim to increase an income of all ethnic groups particularly the Bumiputeras comprising the lower income group which is referred to as B40, the hardcore poor, the economically poor, those in economic transition, Orang Asli, Sabah, Sarawak Bumiputeras, the disabled, youths, women, children and senior citizens (Loheswar, 2019; Zakiah, 2019). It has restructured its past approaches to reduce poverty and inequalities in line with the Sustainable Goal theme 'no one will be left behind'. To become a developed country and sustainbale livelihood, it is very important for Malaysia to alleviate poverty completely and restructure the society. Although the rate of overall poverty in Malaysia has been declining to a negligible percentage, the specific threat from poverty is still noticeable among certain groups as well as certain areas and states. They are still facing big challenges to provide enough opportunities for Income Generating Activities (IGAs) towards low income group to achieve certain standards in certain areas. About $40 \%$ of Malaysian households remain in the low income category, earning less than RM1,500 a month, of which $77.2 \%$ are bumiputera (Nair \& Sagaran, 2015). Besides, the low income still experience social inequity, deprive of access to education, healthcare, credit availability, income opportunity and securing property rights (Courtenay, 1988; Nair, 2001; Nor, 1991; Ali, Kronbak \& Vestergaard, 2011; Rahman, Bhuiyan \& Sina, 2014). This group requires specific policy interventions especially on capability development in order to achieve upward mobility. Income disparities between ethnic groups and regions must still be actively addressed.

The current scenario indicates that Malaysia is no longer just grappling with absolute poverty but also with relative poverty, pockets of persistent poverty, the traditional rural poverty, and urban poverty as well as increasing inequalities. A key feature of a green economy is that it seeks to provide diverse opportunities for economic development and poverty alleviation without liquidating or eroding a country's natural assets (Chua \& Oh, 2011; Kronbak \& Vestergaard, 2011; Nair, 2010). In particular, the ecosystem goods and services comprise a large component of the livelihoods of poor rural communities (Abul, Chamhuri, Abdul, \& Islam, 2012; Ali, FerdausurRahman, Bhuiyan, \& Sina, 2014; Bhuiyan, Chamhuri, Ismail, \& Basri, 2013; Bhuiyan \& Hassan, 2013; Bhuiyan, Siwar, Islam, \& Adhan, 2012; Haque, Siwar, Bhuiyan, \& Joarder, 2019; Haque, Siwar, Ghazali, \& Bhuiyan, 2018). During the Tenth Malaysia Plan (10MP 2011-2015), the bottom group consists of 2.4 million households, with $73 \%$ Bumiputeras (locals) and the remaining $27 \%$ non-Bumiputeras (non-locals). While in the $11 \mathrm{MP}$ 
INTERNATIONAL JOURNAL OF ACADEMIC RESEARCH IN ACCOUNTING, FINANCE AND MANAGEMENT SCIENCES

Vol. 11, No. 3, 2021, E-ISSN: 2225-8329 @ 2021 HRMARS

(2016-2020), there are 2.7 million households' monthly income of RM2,537.00, with 68\% Bumiputeras (locals) and 32\% non-Bumiputeras (non-locals); and 56\% in urban and $44 \%$ in rural areas. This group requires specific policy interventions especially on capability development in order to achieve upward mobility. Income disparities between ethnic groups and regions must still be actively addressed. In such circumstances, the present study conducts a rigorous study on the women empowerment, health safety, education and living standard in Selangor, Malaysia. This research can draw out future direction for the income generating activities (IGAs) in ensuring for health nutrition, basic education, and sustainable living of the poor people including women in Selangor, Malaysia.

\section{Literature Review}

Nair \& Sagaran, in 2015 mentioned that the Malaysia aspires to be a developed nation and if these development ambitions are to be attained Malaysia needs to re-examine its past approaches to reducing poverty and inequalities in the country. Malaysia is no longer just grappling with absolute poverty but also with relative poverty, pockets of persistent poverty and urban poverty as well as increasing inequalities. While rural poverty still continues to be the focus of policymakers, urban poverty also needs urgent policy attention and prescriptions. Stubborn pockets of poverty continue to elude policy solutions and new forms of poverty are emerging in the context of a country that sees itself as a developed nation. Close attention has to be paid to income distribution as progress towards poverty reduction is marred unless improvements in income distribution occur alongside poverty reduction. A paradigm shift is needed in the way in which poverty is conceptualized, defined and measured in Malaysia as the reinterpretation of the Poverty and Income distribution data over the last three decades shows that poverty in Malaysia retains much of its original characteristics and income distribution patterns show inter-ethnic inequalities remaining and a worsening position for certain ethnic groups. The call for a paradigm shift is further reinforced by the new development direction that is encapsulated in the New Economic Model with its focus on inclusive development and the bottom $40 \%$ of the population Nair \& Sagaran, 2015).

Abdullah, Othman, Edo, and Jani, in 2019 introduced the multidimensional poverty index (MPI) as an alternative method of poverty measurement. MPI is capable of identifying "Who is Poor" among the underprivileged in society. The paper aimed to bridge the gap between the Orang Asli society's development and national policy from a multidimensional perspective. The questionnaire used was adapted from the United Nation Development Program of Malaysia (UNDP). The answers were recorded using the binary method, whereby " 1 " is deprived and " 0 " is not deprived. The data were analyzed using the multidimensional analysis. By applying the MPI to the Orang Asli population in Terengganu, the study was able to reveal the factors that have deprived the poor to the point of poverty. There are four dimensions used in this study such as education, health, standard of living, and wealth. The result shows $97.1 \%$ of the Orang Asli in Terengganu are deprived in livestock followed by waste management at $96.6 \%$, years of schooling at $83.4 \%$, and only $58.9 \%$ as an income indicator. The result also indicates that Sungai Pergam village was poorer compared to other villages based on the MPI measured. These findings prove that MPI is able to reveal the real reason behind poverty with accuracy. Therefore, this mode of measurement can also be applied to other targeted groups in order to achieve more effective poverty eradication programs. MPI measurement implemented in this study has successfully covered the objectives of the studies. The results found that most Orang Asli in Terengganu were critically deprived in commercial livestock, waste 
INTERNATIONAL JOURNAL OF ACADEMIC RESEARCH IN ACCOUNTING, FINANCE AND MANAGEMENT SCIENCES

Vol. 11, No. 3, 2021, E-ISSN: 2225-8329 ๑ 2021 HRMARS

management followed by years of schooling and income indicator. Yet, there are other indicators that are of concern such as asset, number of households, home appliances, school enrolment, and sanitation which have less than $50 \%$ deprivation.

Gopal (2018) explored that the poverty has been dominantly an economic concept and dealt with income or expenditure in Malaysia. In many parts of the world, widespread support surface for the application of a multidimensional approach to poverty. Yet, in practice the vast majority of empirical work on poverty uses a unidimensional yardstick to judge a person's well-being, usually expenditure or income per capita. While economic well-being, capability, political, and civic/cultural inclusion are integral parts of a multidimensional concept of poverty, a proper operationalization as well as comprehensive conceptualization of poverty based on multidimensional perspective is still lacking in Malaysia. They used the Multidimensional Poverty Index (MPI to measure of multidimensional perspective and intends to develop a coherent framework for measuring multidimensional poverty index in a smaller scale among the poor B40 Universiti Sains Malaysia (USM) students. The findings of this study are envisaged to ascertain to what extent multidimensional poverty index is valid vis-avis the unidimensional measurement approach in the near future for a bigger scale research, both in the state of Penang and other states in Malaysia (Gopal, 2018).

Ravallion (2020) assessed the role that changes in between-group inequality played in Malaysia's success against poverty. To address this question, a new decomposition method is applied to survey data spanning 50 years. The results indicate that ethnic redistribution helped reduce poverty, but it was not as important as within-group redistribution or mean-income growth. A pure ethnic redistribution effect is defined and isolated empirically. Sizable potential gains to the country's poor from ethnic redistribution are revealed in the 1970s, suggesting that the early policy effort made sense. The absolute gains have faded over time and are now small, though the elasticity of national poverty to ethnic redistribution remains quite high (Ravallion, 2020).

Vaziri et al (2019) mentioned that poverty is one of the most common problems throughout the world. For this reason, United Nations Sustainable Development Goal (SDG) number one aims at its eradication from all countries around the globe. While this is an ambitious goal, it has reinforced the commitment of many countries, including Malaysia, towards increased poverty alleviation efforts. Peninsular Malaysia has over the past decade been making many efforts to reduce poverty among its population. Like many socioeconomic problems, poverty is a function of space, and spatial analysis can be key to deeper understanding and implementation of effectual intervention policies. In the era of advancement of geospatial techniques, many of our socio-economic problems can be explained through spatial analysis, mapping, and visualization. This study's main objective is to illuminate the spatial distribution of poverty and assess the factors that most contribute to the spatial configuration, using hotspot analysis and geographically weighted regression. While the results demonstrate the complexity of poverty as an issue in Malaysia, they demonstrate a clear spatial pattern. Poverty rates in Malaysia are significantly clustered $(p<0.001)$, as most of the high poverty rate sub-districts are located in the north-eastern states of Kelantan and Terengganu. Even though the SDG number one is an ambitious one, this paper has revealed important spatial dynamics that are worthy of consideration as the government implement policies that will eradicate poverty (Vaziri et al., 2019). 
INTERNATIONAL JOURNAL OF ACADEMIC RESEARCH IN ACCOUNTING, FINANCE AND MANAGEMENT SCIENCES

Vol. 11, No. 3, 2021, E-ISSN: 2225-8329 ๔ 2021 HRMARS

Azhar and Mohd (2020) used the Asset index is one of the non-monetary poverty measurements which have been established by researchers but not used in measuring poverty in Malaysia. A household might be poor in income, but assets may prevent them from being trapped in poverty. This study will reassess the poverty of 302 households in the Northern States of Malaysia using the asset index and also the current state of poverty incidence with change under asset index. The results show that households in the Northern States of Malaysia are interpreted as being 'poorer' when poverty is measured using assets as opposed to income alone. Besides that, poverty incidence of Malay households, households living in urban area and households with middle-aged heads have high poverty incidence, while households with a head of households that is single and highly educated have low poverty incidence. The logistic regression analysis shows that the determinants of poverty incidence based on the asset index are Indian, Penang and Perak State, the age of the head of household, distance to the education centre from home. This study shows the asset index measurement which have not been done in Malaysia. This will contribute to the improvement of poverty measurement of the country (Azhar \& Mohd, 2020).

Shong, Abu Bakar, \& Islam, in 2019 used qualitative case study explored the voices of juvenile offenders in Malaysia who were plagued with poverty, and brought to light their plight. The purpose of this study was to examine the effects of poverty on the delinquent character and behavioural development of the children on three major crime-enhancing themes - miserable family conditions, school failure and association with deviant peers - to get a broader view of how poverty could influence their life trajectory. The purposive maximum variation sampling method was used in the selection of six young offenders between the ages of 13 and 17 years from Sekolah Tunas Bakti Sungai Besi, Kuala Lumpur, Malaysia. A multiple data collection method that included observation, in-depth case study and document analysis was used for data collection. Results showed that three major crime-enhancing themes due to poverty were strongly related to children's delinquent character and behavioural development. The knowledge gained from this study will further contribute to understanding the real-life experiences of juvenile offenders, particularly those who are experiencing extreme deprivation, and it is hoped that the insight gained could help in the prevention and control of juvenile delinquent behaviour in Malaysia (Shong et al., 2019).

Abdul Rahman et al (2021) The Multidimensional Poverty Index (MPI) is an income-based poverty index which measures multiple deprivations alongside other relevant factors to determine and classify poverty. The implementation of a reliable MPI is one of the significant efforts by the Malaysian government to improve measures in alleviating poverty, in line with the recent policy for Bottom 40 Percent (B40) group. However, using this measurement, only $0.86 \%$ of Malaysians are regarded as multidimensional poor, and this measurement was claimed to be irrelevant for Malaysia as a country that has rapid economic development. Therefore, this study proposes a B40 clusteringbased K-Means with cosine similarity architecture to identify the right indicators and dimensions that will provide data driven MPI measurement. In order to evaluate the approach, this study conducted extensive experiments on the Malaysian Census dataset. A series of data pre-processing steps were implemented, including data integration, attribute generation, data filtering, data cleaning, data transformation and attribute selection. The clustering model produced eight clusters of B40 group. The study included a comprehensive clustering analysis to meaningfully understand each of the clusters. The analysis discovered seven indicators of multidimensional poverty from three dimensions 
INTERNATIONAL JOURNAL OF ACADEMIC RESEARCH IN ACCOUNTING, FINANCE AND MANAGEMENT SCIENCES

Vol. 11, No. 3, 2021, E-ISSN: 2225-8329 @ 2021 HRMARS

encompassing education, living standard and employment. Out of the seven indicators, this study proposed six indicators to be added to the current MPI to establish a more meaningful scenario of the current poverty trend in Malaysia. The outcomes from this study may help the government in properly identifying the B40 group who suffers from financial burden, which could have been currently misclassified (Abdul Rahman et al., 2021).

Samsudin and Nadzrulizam (2021) Income inequality has become a major economic growth problem faced by most countries in the world. The income gap that exists between the rich and the poor grows wider every year. The Malaysian government have set up multiple economic policies and provided various aids that focuses on improving the B40's economic situation and reduce the income gap that exist amongst them. Data for this study are obtained from the Household Income Survey (HIS). This study makes the comparison on the range and average of income amongst the B40 household income of each state in Malaysia. This comparison analyses the income gap that exist amongst the local households. Income inequalities amongst B40 households are prominent in Selangor, which recorded a huge income gap amongst the households. Kelantan has the lowest maximum and average income value amongst B40 from all states. The demographic factors that have significant impacts on the distribution of income amongst the B40 population in Malaysia was analysed using regression models. Residential area, levels of academic studies and working status of the head of household are the factors that effects B40 populations in Malaysia (Samsudin \& Nadzrulizam, 2021).

\section{Method}

The study utilises a quantitative approach in analysing the primary data from 404 samples. A survey questionnaire was developed to collect data on multidementional deprivation information from the B40 groups residing in Selangor. A purposive stratified random sampling method was used to select the respondents based on the nine districts of Selangor comprising Gombak, Klang, Kuala Langat, Kuala Selangor, Petaling, Sabak Bernam, Sepang, Hulu Langat, and Hulu Selangor. According to the Department of Statistic Malaysia (DOSM, 2019), 17\% of the population is categorised as B40 (DOSM, 2019 ) indicating that a total of 4,932,695 of population in Selangor are considered as B40 group. The study considers only 838,558 as total population and total suggested sample is 404 respondents based on the 17\% B40 groups residing in Selangor and based of the percentage of population, races and districts respectively. Table 1 shows the level of confidence of the sampling.

Table 1: Selection of Sampling

\begin{tabular}{|l|r|}
\hline Number of sample & 404 \\
\hline Level of confidence & $95 \%$ \\
\hline Percentage of errors & $5 \%$ \\
\hline
\end{tabular}

Descriptive statistics, econometric techniques, and Malaysian Human Poverty Index (MPHI) are applied in the analysis. The present study utilises multiple logistic regression models to estimate the parameters that influence the status of the poor. The Multidimensional Poverty Index (MPI) which was developed by Alkire and Santos $(2010,2013)$ in collaboration with the UNDP, and first appeared in the 2010 Human Development Report, is one particular adaptation of the adjusted headcount ratio 
(M0) proposed in Alkire and Foster (2014) and expanded on in (Alkire et al., 2015). They extended the Foster Greer Thorbecke (1984) unidimensional poverty methodology, in identifying poor by considering the intensity of deprivations that they suffer and includes an aggregation method. The multidimensional Poverty uses a range of indicators that have deprived by the standard set of indicators, dimensions, cut offs and thresholds used among the poor household. The MPI was developed in 2010 by the Oxford Poverty and Human Development Initiative (OPHI) and the United Nations Development Program and it utilises health, education, and standard of living indicators to determine the degree of poverty experienced by a population. It has replaced the Human Poverty Index and designed by the deprivation score of the number of indicators and the 'weights' assigned to the dimensions in the category of Health, Education, Standard of Living, etc.

Moreover, as shown in Table 2 ten dimensions are considered as the deprivation situation in poor households especially for education deprivation: 1. Years of Schooling 2. School attendance, for Health deprivation; 1 . Access to Health Facilities, 2. Access to clean water supply, the standard of living deprivation; 1 . Condition of the living quarters, 2. The number of bedrooms, 3. Toilet Facilities, 4. Garbage Collection facilities, 5. Transportations, and 6. Access of Communication tools etc. In Malaysia, the MPI complements the Poverty Line Income (PLI) to measure and monitor poverty from a multidimensional perspective. In contrast to PLI which measures absolute poverty that is based solely on income dimension, the MPI measures poverty in multiple dimensions. The MPI reflects both the incidence of multidimensional deprivation (the number of people who suffer deprivations in multiple aspects of life at a particular period within a given population), and its intensity (how many deprivations they experience at a particular period). The households in Selangor that satisfy the criteria will be selected.

Measurement of the MPI:

$\mathrm{MPI}=\mathrm{H} \times \mathrm{A}$

$\mathrm{H}=$ Incidence: the percentage of people who are multidimensional poor, or the headcount $A=$ Intensity of people's poverty: the average percentage of dimensions in which poor people are deprived. 
INTERNATIONAL JOURNAL OF ACADEMIC RESEARCH IN ACCOUNTING, FINANCE AND MANAGEMENT SCIENCES

Vol. 11, No. 3, 2021, E-ISSN: 2225-8329 @ 2021 HRMARS

Table 2: Measurement of the Multidimensional Dimensions, Indicators, Deprivation cut-offs, and Weights

\begin{tabular}{|l|l|c|}
\hline Cut off Dimension & \multicolumn{1}{|c|}{ Deprivation } & Weight \\
\hline Years of Schooling & $\begin{array}{l}\text { Education years of schooling all household } \\
\text { members aged 13-60 have less than 6 years } \\
\text { of education school attendance }\end{array}$ & $1 / 8$ \\
\hline School attendance & $\begin{array}{l}\text { Any school-aged children (aged 6-16) not } \\
\text { schooling }\end{array}$ & $1 / 8$ \\
\hline $\begin{array}{l}\text { Access of Health } \\
\text { Facilities }\end{array}$ & $\begin{array}{l}\text { Health access to healthcare facility are the } \\
\text { distance more than 5 kilometers away }\end{array}$ & $1 / 8$ \\
\hline $\begin{array}{l}\text { Access of clean water } \\
\text { supply }\end{array}$ & $\begin{array}{l}\text { Access to clean water other than treated } \\
\text { pipe water inside house and public water } \\
\text { pipe/stand pipe }\end{array}$ & $1 / 8$ \\
\hline $\begin{array}{l}\text { Condition of living } \\
\text { quarter }\end{array}$ & $\begin{array}{l}\text { Standard of living conditions of living } \\
\text { quarters dilapidated or deteriorating }\end{array}$ & $1 / 24$ \\
\hline Room crowdedness (number of bedrooms) \\
more than 2 household members in a \\
bedroom
\end{tabular}

Source:11th. Malaysia Plan, 2018

\section{Findings}

\section{Age Range of Respondents}

Table 3 shows the most common age range of the respondent of lower income group in Selangor, Malaysia. The majority of them are in the range of $41-50$ years old $25 \%$ which is followed by the $31-$ 40 years old group 23.26\%, 18-30 years old group 20.54\%, in the same way, 51-60 years-old group $18.70 \%$, and the 65 to 71 or older age group 13.12 in the state of Selangor, Malaysia respectively. 
INTERNATIONAL JOURNAL OF ACADEMIC RESEARCH IN ACCOUNTING, FINANCE AND MANAGEMENT SCIENCES

Vol. 11, No. 3, 2021, E-ISSN: 2225-8329 @ 2021 HRMARS

Table 3: Age Range of Respondents

\begin{tabular}{|l|l|l|}
\hline \multicolumn{3}{|c|}{ Age Range of Respondents } \\
\hline & Frequency & Percent \\
\hline $18-30$ & 83 & 20.54 \\
\hline $31-40$ & 94 & 23.26 \\
\hline $41-50$ & 101 & 25 \\
\hline $51-60$ & 73 & 18.70 \\
\hline $61-$ Above & 53 & 13.12 \\
\hline Total & 404 & 100 \\
\hline
\end{tabular}

\section{Respondents Level of Education}

Table 4 presents the education level of the respondents as an important factor to determine how it influences the total household status of the respondent. The present study reveals that $32.9 \%$ of respondent have upper secondary level of education, where are $29.7 \%$ are from Higher Education level. The study also revealed that $10.4 \%$ are at the lower-level education but only $11.1 \%$ of responses have no formal education respectively.

Table 4: Respondents level of education

\begin{tabular}{|l|l|l|}
\hline \multicolumn{2}{|c|}{ Education } \\
\hline & Frequency & Percent \\
\hline No formal education & 45 & 11.1 \\
\hline Primary school (Year 1-6) & 22 & 5.4 \\
\hline Lower secondary (Form 1-3) & 42 & 10.4 \\
\hline Upper secondary (Form 4-5) & 133 & 32.9 \\
\hline Post-secondary Vocational/Technical & 34 & 8.4 \\
\hline Hut schools (religious) & 5 & 1.2 \\
\hline $\begin{array}{l}\text { Higher } \\
\text { (polytechnic/college/university) }\end{array}$ & 120 & 29.7 \\
\hline Others & 3 ducation & 120 \\
\hline Total & 3 & 0.7 \\
\hline
\end{tabular}

\section{Household Members of the Respondents}

Table 5 indicates that the average number among the lower income group in Selangor, Malaysia. The study found that the $12.1 \%$ of family have only one family members and whereas, $26.7 \%$ of them have two family's member's among the lower income group in Selangor, Malaysia. The study also discovered that average household members is 3.60 persons, whereas the standard deviation of household size 1.87 among the lower income group in Selangor, Malaysia respectively. 
INTERNATIONAL JOURNAL OF ACADEMIC RESEARCH IN ACCOUNTING, FINANCE AND MANAGEMENT SCIENCES

Vol. 11, No. 3, 2021, E-ISSN: 2225-8329 @ 2021 HRMARS

Table 5: Distribution of Household Members of the Respondents

\begin{tabular}{|l|l|l|}
\hline \multicolumn{2}{|c|}{ Household Members } \\
\hline & Frequency & Percent \\
\hline 1 & 49 & 12.1 \\
\hline 2 & 108 & 26.7 \\
\hline 3 & 35 & 8.7 \\
\hline 4 & 81 & 20.0 \\
\hline 5 & 64 & 15.8 \\
\hline 6 & 40 & 9.9 \\
\hline 7 & 18 & 4.5 \\
\hline 8 & 6 & 1.5 \\
\hline 9 & 2 & .5 \\
\hline 10 & 1 & .2 \\
\hline Mean & 3.6040 & \\
\hline Std. Div & 1.87224 & \\
\hline
\end{tabular}

\section{Earning Members in the Household}

Table 6 shows earning members in the household among the lower income group in Selangor, Malaysia. The total number of earning household members is an important factor in the increase of income of households. The total number of earning members is the number of the family members who are employed or engaged in IGAs. The general assumption is the household income is higher if the number of earning members is higher, while other relevant factors remain constant. The present study used the total number of earning members as an important indicator to determine how the number of earning members influenced the total household income of the B40 income groups.

Table 6: Earning Distribution of Household Members

\begin{tabular}{|l|l|l|}
\hline \multicolumn{2}{|c|}{ Earning Members of Household } \\
\hline & Frequency & Percent \\
\hline 1 & 221 & 54.7 \\
\hline 2 & 85 & 21.0 \\
\hline 3 & 57 & 14.1 \\
\hline 4 & 32 & 7.9 \\
\hline 5 & 6 & 1.5 \\
\hline 6 & 3 & .7 \\
\hline Mean & 1.8267 & \\
\hline Std. Div & 1.10926 & \\
\hline
\end{tabular}

The study also reveals that $54.7 \%$ of families who have only one earning members Household among the lower income group in Selangor, Malaysia. The majority $21 \%$ of the families have two members engaged in IGAs, and, there are $14.1 \%$ of the families have three earning members, moreover, only $7.9 \%$ of the families have three earning members. Finally, 1.5 and .7 of the families have five and six more earning family members. The table also shows that there are 1.83 average earning members 
INTERNATIONAL JOURNAL OF ACADEMIC RESEARCH IN ACCOUNTING, FINANCE AND MANAGEMENT SCIENCES

Vol. 11, No. 3, 2021, E-ISSN: 2225-8329 @ 2021 HRMARS

whereas $1.10 \mathrm{Std}$. Deviation of earning members respectively among the lower income group in Selangor, Malaysia.

\section{Range of Total Household Income}

Table 7 shows the range of total household income respondent family among the lower income group in Selangor, Malaysia. The study found that $39.1 \%$ of family have less than RM2,500 of their household monthly income. Whereas only $16.1 \%$ of the respondents retained having an income around RM 2501 - RM 3,000 respectively. However, $13.1 \%$ of the family have income range between RM 4, 501 - RM 5, 000. Moreover, 11.4\% of the respondent's incomes that ranged from RM 3,001RM 3,500 and only $11.1 \%$ and 9.2\% increased incomes within the range RM 3,501 - RM 4,000 and RM 4, 001 - RM 4,500 respectively.

Table 7: Range and Total Amount of Income

\begin{tabular}{|l|l|l|}
\hline \multicolumn{2}{|l|}{ Income level } \\
\hline & Frequency & Percent \\
\hline Less than RM2,500 & 158 & 39.1 \\
\hline RM 2501 - RM 3,000 & 65 & 16.1 \\
\hline RM 3,001 - RM 3,500 & 46 & 11.4 \\
\hline RM 3,501 - RM 4,000 & 45 & 11.1 \\
\hline RM 4, 001 - RM 4,500 & 37 & 9.2 \\
\hline RM 4, 501 - RM 5, 000 & 53 & 13.1 \\
\hline Total & 404 & 100 \\
\hline
\end{tabular}

\section{Household Member Contribution in the Income Structure}

Table 8 shows the household members contribution in the Income structure among the lower income group in Selangor, Malaysia. The study shows that $56.7 \%$ of household income is contributed from paid employment, $39.4 \%$ of income of the household from self-employment, $19.6 \%$ of income derived from paid wages of odd jobs as well as 3.2\% of income from Transfers received from different relatives among the lower income group in Selangor, Malaysia.

Table 8: Household Member Contribution in the Income Structure

\begin{tabular}{|l|l|l|}
\hline \multicolumn{2}{|c|}{ Source of Household Income } \\
\hline & Frequency & Percent \\
\hline Rent/ASN/ASB/LUTH & 14 & 3.5 \\
\hline Income from self-employment & 159 & 39.4 \\
\hline Income from paid employment & 229 & 56.7 \\
\hline Income from paid wages (Odd jobs) & 79 & 19.6 \\
\hline Transfers received & 13 & 3.2 \\
\hline Other sources & 103 & 25.5 \\
\hline
\end{tabular}


INTERNATIONAL JOURNAL OF ACADEMIC RESEARCH IN ACCOUNTING, FINANCE AND

MANAGEMENT SCIENCES

Vol. 11, No. 3, 2021, E-ISSN: 2225-8329 @ 2021 HRMARS

\section{Total Household Assets of the Respondents}

Table 9 shows the distribution of the total household assets of the respondent household among the lower income group in Selangor, Malaysia. The study result revealed that the average the total assets of the respondents were RM 21,690 among the lower income group in Selangor, Malaysia.

Table 9: Distribution of Total Household Assets of the Respondents

\begin{tabular}{|l|c|}
\hline \multicolumn{2}{|c|}{ Household Assets } \\
\hline Average & 21690.71 \\
\hline Std.Div & 47045.4 \\
\hline
\end{tabular}

The Multidimensional Livelihood Deprivations

Adult Years of Schooling

Table 10 shows there are about $83.9 \%$ the number of households aged 13-60 years old had no deprivation on the years of schooling adult among lower income group in Selangor, Malaysia. Moreover, there are $16.1 \%$ household still deprived from adult schooling respectively.

Table 10: Adult Years of Schooling

\begin{tabular}{|l|l|l|}
\hline \multicolumn{3}{|c|}{ Adult Years of Schooling } \\
\hline Items & Frequency & Percent (\%) \\
\hline No deprivation & 339 & 83.9 \\
\hline Deprivation & 65 & 16.1 \\
\hline Total & 404 & 100 \\
\hline
\end{tabular}

\section{School Attendance for Children}

Table 11 shows the number of household's children aged 6-16 years old about 96\% had no deprivation on the years of schooling adult among lower income group in Selangor, Malaysia. Moreover, $4 \%$ household children are still deprived from schooling respectively.

Table 11: School Attendance of Children

\begin{tabular}{|l|l|l|}
\hline \multicolumn{3}{|c|}{ School Attendance of Children } \\
\hline Items & Frequency & Percent (\%) \\
\hline No deprivation & 388 & 96 \\
\hline Deprivation & 16 & 4 \\
\hline Total & 404 & 100 \\
\hline
\end{tabular}

\section{Access of Health Facilities}

Table 12 shows the Access of Health Facilities in the distance of $5 \mathrm{~km}$ and there is no mobile health care access is considered as household's deprivation on the Access of Health Facilities among lower income group in Selangor, Malaysia. The study found that there are $76.7 \%$ are out of deprivation and there are $23.3 \%$ household still deprived in the distance of $5 \mathrm{~km}$ and there is no mobile health care access respectively. 
INTERNATIONAL JOURNAL OF ACADEMIC RESEARCH IN ACCOUNTING, FINANCE AND MANAGEMENT SCIENCES

Vol. 11, No. 3, 2021, E-ISSN: 2225-8329 @ 2021 HRMARS

Table 12: Access of Health Facilities

\begin{tabular}{|l|l|l|}
\hline \multicolumn{3}{|c|}{ Access of Health Facilities } \\
\hline Items & Frequency & Percent (\%) \\
\hline No deprivation & 310 & 76.7 \\
\hline Deprivation & 94 & 23.3 \\
\hline Total & 404 & 100 \\
\hline
\end{tabular}

\section{Access of Clean Water Supply}

Table 13 shows the access of clean water supply other than pipe water inside house and public water pipe considered as household's deprivation on the Access of clean water supply among lower income group in Selangor, Malaysia. The study found that there are $77.2 \%$ are out of deprivation and there are $22.8 \%$ household still deprived in the access of clean water supply respectively.

Table 13: Access of clean water supply

\begin{tabular}{|l|l|l|}
\hline \multicolumn{3}{|c|}{ Access of clean water supply } \\
\hline Items & Frequency & Percent (\%) \\
\hline No deprivation & 312 & 77.2 \\
\hline Deprivation & 92 & 22.8 \\
\hline Total & 404 & 100 \\
\hline
\end{tabular}

\section{Access Condition of Living Quarter}

Table 14 shows the Access condition of living quarter is considered as household's deprivation on the Access of standard of living quarter facilities among lower income group in Selangor, Malaysia. The study found that there are $36.1 \%$ are out of deprivation and there are $63.9 \%$ household still deprived in the on the Access of standard of living quarter access respectively.

Table 14: Condition of living quarter

\begin{tabular}{|l|l|l|}
\hline \multicolumn{3}{|c|}{ Condition of living quarter } \\
\hline Items & Frequency & Percent (\%) \\
\hline No deprivation & 146 & 36.1 \\
\hline Deprivation & 258 & 63.9 \\
\hline Total & 404 & 100 \\
\hline
\end{tabular}

\section{Number of Bed Rooms}

Table 15 shows the Access number of bed room condition of living quarter is considered as household's deprivation on the if more than two household's members are living in a room among lower income group in Selangor, Malaysia. The study found that there are $35.9 \%$ are out of deprivation and there are $64.1 \%$ household still deprived in the on the Access of separate living room in the living quarter respectively. 
INTERNATIONAL JOURNAL OF ACADEMIC RESEARCH IN ACCOUNTING, FINANCE AND MANAGEMENT SCIENCES

Vol. 11, No. 3, 2021, E-ISSN: 2225-8329 @ 2021 HRMARS

Table 15: Number of bed rooms

\begin{tabular}{|l|l|l|}
\hline \multicolumn{3}{|c|}{ Number of Bed Rooms } \\
\hline Items & Frequency & Percent (\%) \\
\hline No deprivation & 145 & 35.9 \\
\hline Deprivation & 259 & 64.1 \\
\hline Total & 404 & 100 \\
\hline
\end{tabular}

\section{Toilet Facilities}

Table 16 shows the Access number of bed room condition of toilet facilities is considered as household's deprivation on the if there are no flash toilet facilities in the living room after among lower income group in Selangor, Malaysia. The study found that there are $87.1 \%$ are out of deprivation and there are $12.9 \%$ household still deprived in the on the Access of flash toilet facilities in the living quarter respectively.

Table 16: Toilet Facilities

\begin{tabular}{|l|l|l|}
\hline \multicolumn{3}{|c|}{ Toilet Facilities } \\
\hline Items & Frequency & Percent (\%) \\
\hline No deprivation & 352 & 87.1 \\
\hline Deprivation & 52 & 12.9 \\
\hline Total & 404 & 100 \\
\hline
\end{tabular}

\section{Garbage Collection Facilities}

Table 17 shows the garbage collection facilities which is considered as household's deprivation if there are no garbage collection facilities in the living area among lower income group in Selangor, Malaysia. The study found that there are $85.9 \%$ are out of deprivation and there are $14.1 \%$ household still deprived in the on the access of garbage collection facilities in the living quarter respectively.

Table 17: Garbage Collection Facilities

\begin{tabular}{|l|l|l|}
\hline \multicolumn{3}{|c|}{ Garbage Collection Facilities } \\
\hline Items & Frequency & Percent (\%) \\
\hline No deprivation & 347 & 85.9 \\
\hline Deprivation & 57 & 14.1 \\
\hline Total & 404 & 100 \\
\hline
\end{tabular}

\section{Transportation}

Table 18 shows the transportation facilities which is considered all household members don't have private or public among lower income group in Selangor, Malaysia. The study found that there are $84.9 \%$ are out of deprivation and there are $15.1 \%$ household still deprived in the on the access of transportations facilities in the living area respectively. 
INTERNATIONAL JOURNAL OF ACADEMIC RESEARCH IN ACCOUNTING, FINANCE AND MANAGEMENT SCIENCES

Vol. 11, No. 3, 2021, E-ISSN: 2225-8329 @ 2021 HRMARS

Table 18: Transportation

\begin{tabular}{|l|l|l|}
\hline \multicolumn{3}{|c|}{ Transportation } \\
\hline Items & Frequency & Percent (\%) \\
\hline No deprivation & 343 & 84.9 \\
\hline Deprivation & 61 & 15.1 \\
\hline Total & 404 & 100 \\
\hline
\end{tabular}

\section{Communication Tools}

Table 19 shows the access of basic communication tools which is considered that all household members don't have fixed phone line or mobile number among lower income group in Selangor, Malaysia. The study found that there are $53.2 \%$ are out of deprivation and there are $46.8 \%$ household still deprived in the on the access of basic communication tools respectively.

Table 19: Communication Tools

\begin{tabular}{|l|l|l|}
\hline \multicolumn{3}{|c|}{ Communication tools } \\
\hline Items & Frequency & Percent (\%) \\
\hline No deprivation & 215 & 53.2 \\
\hline Deprivation & 189 & 46.8 \\
\hline Total & 404 & 100 \\
\hline
\end{tabular}

\section{Education Poverty}

Table 20 shows the number of households that have education deprivation among the lower -income group in Selangor, Malaysia. In case of years of schooling, $2.01 \%$ of family have average deprivation, whereas intensity of poverty index values is $16.08 \%$ and Multidimensional Poverty (MPI) is 0.0032 respectively. However, in the case of school attendance $0.49 \%$ of family have average deprivation, whereas intensity of poverty index values is $3.96 \%$ and Multidimensional Poverty (MPI) is 0.00019 respectively. Finally, average Incidence of Poverty $1.25 \%$, Intensity of poverty Index for depth of deprivation on about $2.51 \%$ and Multidimensional education poverty (MPI) is 0.0017 respectively.

Table 20: Education Poverty

\begin{tabular}{|l|l|l|l|l|}
\hline Particulars & \multicolumn{3}{|l|}{ Education Poverty } & \\
\cline { 2 - 6 } & $\begin{array}{l}\text { Years of } \\
\text { schooling }\end{array}$ & $\begin{array}{l}\text { School } \\
\text { attendance }\end{array}$ & Education poverty & \\
\hline Average Incidence of Poverty & 2.01 & 0.49 & 1.255 & 0.025 \\
\hline $\begin{array}{l}\text { Intensity of poverty Index } \\
\text { Values }\end{array}$ & 0.16 & 0.039 & 2.51 & \\
\hline Intensity of poverty Index (\%) & 16.08 & 3.96 & 0.0017 & \\
\hline $\begin{array}{l}\text { Multidimensional Poverty } \\
\text { (MPI) }\end{array}$ & 0.0032 & 0.00019 & & \\
\hline
\end{tabular}

\section{Health Poverty}

Table 21 shows the number of households have health deprivation among lower income group in Selangor, Malaysia. In case access of health facilities $0.96 \%$ of family have average deprivation, 
INTERNATIONAL JOURNAL OF ACADEMIC RESEARCH IN ACCOUNTING, FINANCE AND MANAGEMENT SCIENCES

Vol. 11, No. 3, 2021, E-ISSN: 2225-8329 @ 2021 HRMARS

whereas intensity of poverty index values is $7.67 \%$ and Multidimensional Poverty (MPI) is 0.0007 respectively. However, in the case of access of clean water supply $2.94 \%$ of family have average deprivation, whereas intensity of poverty index values is $23.51 \%$ and Multidimensional Poverty (MPI) is 0.0069 respectively. Finally, average Incidence of health Poverty $1.95 \%$, Intensity of poverty Index for depth of deprivation on about $3.98 \%$ and Multidimensional education poverty (MPI) is 0.0038 respectively.

Table 21: Health Poverty

\begin{tabular}{|l|l|l|l|l|}
\hline Particulars & \multicolumn{3}{|l|}{ Health Poverty } & \\
\cline { 2 - 5 } & $\begin{array}{l}\text { Access of } \\
\text { Health } \\
\text { Facilities }\end{array}$ & $\begin{array}{l}\text { Access of clean } \\
\text { water supply }\end{array}$ & Health Poverty & 1.949 \\
\hline $\begin{array}{l}\text { Average Incidence of } \\
\text { Poverty }\end{array}$ & 0.9591 & 2.939 & 0.039 & 3.98 \\
\hline $\begin{array}{l}\text { Intensity of poverty Index } \\
\text { Values }\end{array}$ & 0.0767 & 0.232 & 0.0038 & \\
\hline $\begin{array}{l}\text { Intensity of poverty Index } \\
\text { (\%) }\end{array}$ & 7.6732 & 23.514 & 0.0069 & \\
\hline $\begin{array}{l}\text { Multidimensional Poverty } \\
\text { (MPI) }\end{array}$ & 0.0007 & & & \\
\hline
\end{tabular}

\section{Standard of Living Poverty}

Table 22 shows the number of households have standard of living deprivation among lower income group in Selangor, Malaysia. In case of condition of living quarter $7.98 \%$ of family have average deprivation, whereas intensity of poverty index values is $63.86 \%$ and Multidimensional Poverty (MPI) is 0.051 respectively. In case access of number of bed rooms $8.01 \%$ of family have average deprivation, whereas intensity of poverty index values is $64.11 \%$ and Multidimensional Poverty (MPI) is 0.051 respectively. In case access of Toilet facilities $1.6 \%$ of family have average deprivation, whereas intensity of poverty index values is $12.87 \%$ and Multidimensional Poverty (MPI) is 0.002 respectively. In case access of Garbage Collection facilities $1.76 \%$ of family have average deprivation, whereas intensity of poverty index values is $14.11 \%$ and Multidimensional Poverty (MPI) is 0.002 respectively. In case access of Transportations facilities $1.88 \%$ of family have average deprivation, whereas intensity of poverty index values is $15.1 \%$ and Multidimensional Poverty (MPI) is 0.002 respectively. In case access of Access of Communication tools $5.84 \%$ of family have average deprivation, whereas intensity of poverty index values is $46.78 \%$ and Multidimensional Poverty (MPI) 0.027 respectively. Finally, average Incidence of $4.51 \%$, Intensity of poverty Index for depth of deprivation on about $36.14 \%$ and Multidimensional education poverty (MPI) is 0.022 respectively. There are Garbage Collection facilities considered most deprivation and consequently Number of bed rooms respectively. 
INTERNATIONAL JOURNAL OF ACADEMIC RESEARCH IN ACCOUNTING, FINANCE AND MANAGEMENT SCIENCES

Vol. 11, No. 3, 2021, E-ISSN: 2225-8329 @ 2021 HRMARS

Table 22: Standard of living Poverty

\begin{tabular}{|c|c|c|c|c|c|c|c|}
\hline \multirow[t]{2}{*}{ Particulars } & & \multirow[b]{2}{*}{$\begin{array}{l}\text { Toilet } \\
\text { Faciliti } \\
\text { es }\end{array}$} & \multirow[b]{2}{*}{$\begin{array}{l}\text { Garbage } \\
\text { Collectio } \\
\mathrm{n} \\
\text { facilities }\end{array}$} & \multirow[b]{2}{*}{$\begin{array}{l}\text { Transportati } \\
\text { on facilities }\end{array}$} & \multirow[b]{2}{*}{$\begin{array}{l}\text { Access of } \\
\text { Communicati } \\
\text { on tools }\end{array}$} & \multirow[b]{2}{*}{$\begin{array}{l}\text { Avg. } \\
\text { Std. } \\
\text { of } \\
\text { livin } \\
\text { g }\end{array}$} \\
\hline & $\begin{array}{l}\text { Conditio } \\
\mathrm{n} \quad \text { of } \\
\text { living } \\
\text { quarter }\end{array}$ & $\begin{array}{l}\text { Numbe } \\
\text { r of bed } \\
\text { rooms }\end{array}$ & & & & & \\
\hline $\begin{array}{l}\text { Incidence of } \\
\text { Poverty (\%) }\end{array}$ & 7.98 & 8.01 & 1.6 & 1.76 & 1.88 & 5.84 & 4.51 \\
\hline $\begin{array}{l}\text { Intensity of } \\
\text { poverty Index } \\
\text { Values }\end{array}$ & 0.63 & 0.64 & 0.13 & 0.14 & 0.15 & 0.47 & .36 \\
\hline $\begin{array}{l}\text { Intensity of } \\
\text { poverty Index } \\
(\%)\end{array}$ & 63.86 & 64.11 & 12.87 & 14.11 & 15.1 & 46.78 & $\begin{array}{l}36.1 \\
4\end{array}$ \\
\hline $\begin{array}{l}\text { Multidimensio } \\
\text { nal Poverty } \\
\text { (MPI) }\end{array}$ & 0.051 & 0.051 & 0.002 & 0.002 & 0.002 & 0.027 & $\begin{array}{l}0.02 \\
2\end{array}$ \\
\hline
\end{tabular}

The Multidimensional Poverty Index (MPI) Measurement

The Multidimensional Poverty Index (MPI) complements the Poverty Line Income (PLI) to measure and monitor poverty from multidimensional perspective. In contrast to PLI which measures absolute poverty based solely on income dimension, the MPI measures poverty in multiple dimensions. The MPI reflects both the incidence of multidimensional deprivation (the number of people who suffer deprivations in multiple aspects of life at a particular period within a given population), and its intensity (how many deprivations they experience at a particular period). This Index offers incidenceand intensity-based analysis, thus providing clear identification of the development gaps. This will enable stakeholders to develop more integrated interventions to uplift the income and wellbeing of the target groups. As shown in Table 23, the overall incidence of deprivation at national level improved from $29.73 \%$ in 2018 where it was $30.51 \%$ in 2016 .In the incidence of deprivation for most indicators improved during the period in the three indicators, namely access to $1.26 \%$ whereas healthcare deprivation was $1.95 \%$ as well as standard of living deprivation was $4.51 \%$ of households respectively. Moreover, intensity or deprivation gap in the category of indicators $2.51 \%, 3.98 \%$, $36.14 \%$ are considered as education deprivation, healthcare deprivation and standard of living deprivation respectively. In the same way, average incidence of deprivation for most indicators improved during the period in the three indicators is $1.93 \%$. Moreover, intensity or deprivation gap in the category of indicators $15.44 \%$ accordingly, whereas the Multidimensional Poverty Index (MPI) was 0.0029 or .29\% respectively among lower income group in Selangor, Malaysia. 
INTERNATIONAL JOURNAL OF ACADEMIC RESEARCH IN ACCOUNTING, FINANCE AND MANAGEMENT SCIENCES

Vol. 11, No. 3, 2021, E-ISSN: 2225-8329 @ 2021 HRMARS

Table 23: Overall Multidimensional Poverty Index (MPI) measurement

\begin{tabular}{|c|c|c|c|c|}
\hline \multirow[t]{2}{*}{ Particulars } & \multicolumn{4}{|c|}{ Overall Multidimensional Poverty Index } \\
\hline & $\begin{array}{l}\text { Education } \\
\text { Poverty }\end{array}$ & $\begin{array}{l}\text { Health } \\
\text { Poverty }\end{array}$ & $\begin{array}{l}\text { Standard of Living } \\
\text { Poverty }\end{array}$ & Overall \\
\hline $\begin{array}{l}\text { Average } \\
\text { Incidence } \\
\text { Poverty }\end{array}$ & 1.255 & 1.949 & 4.51 & 1.93 \\
\hline $\begin{array}{l}\text { Intensity of } \\
\text { poverty Index } \\
\text { Values }\end{array}$ & 0.025 & 0.039 & .36 & 0.154 \\
\hline $\begin{array}{l}\text { Intensity of } \\
\text { poverty Index (\%) } \\
\text { Multidimensional } \\
\text { Poverty (MPI) }\end{array}$ & 2.51 & 3.98 & 36.14 & 15.44 \\
\hline
\end{tabular}

\section{Conclusions}

The present study examines the status of household freedom of decision making among lower income group in Selangor, Malaysia. The findings indicate that $48.3 \%$ which represents the majority of respondents are involved with full time employments, whereas $17.8 \%$ of respondents are engaged in self-employment, Micro business, and small business for income generating activities. However, the study also found that $53.2 \%$ of responds are engaged in semi-skilled jobs, and $28.5 \%$ of them are attached to low-skilled whereas only $18.3 \%$ of them have skills in line with their occupational level. In the same way, the findings also reveal that $52.2 \%$ of the respondents' main household head are not working, and $47.8 \%$ of them are working full-time. The study found that $51 \%$ of the respondents are headed by adult male whereas $23.3 \%$ are headed by elderly male-headed. Moreover, $56.7 \%$ of household income is contributed from paid employment, $39.4 \%$ from self-employment, $19.6 \%$ of income derived from odd jobs. In terms of the number of people living in a family, the study found that $31.2 \%$ of family has only one family member whereas $14.6 \%$ of them have two family members. However, the study also reveals that $54.5 \%$ of families have only one member that is earning. In the case of monthly household income, the study also reveals that $39.1 \%$ of family have less than $\mathrm{RM} 2,500$ of their household monthly income.

In the present study, the Multidimensional Poverty Index (MPI) complements the Poverty Line Income (PLI) to measure and monitor poverty from multidimensional perspective. This Index offers incidence and intensity-based analysis; therefore, it provides clear identification of the poverty gaps. This will enable stakeholders to develop more integrated interventions to uplift the income and wellbeing of the target groups. Based on Multidimensional Poverty Index (MPI) result, the study revealed that overall incidence of deprivation to the access of basic education among the households was $1.26 \%$, access to basic healthcare deprivation was $1.95 \%$ and standard of living deprivation $4.51 \%$ among lower income group in Selangor, Malaysia consequently. The study also checked intensity or deprivation gap within the above category of indicators and concluded that there are $2.51 \%$ still away from basic education access, 3.98\% for basic healthcare, $36.14 \%$ of them are in standard of living deprivation stage among lower income group in Selangor, Malaysia. Finally, the present study 
INTERNATIONAL JOURNAL OF ACADEMIC RESEARCH IN ACCOUNTING, FINANCE AND

MANAGEMENT SCIENCES

Vol. 11, No. 3, 2021, E-ISSN: 2225-8329 @ 2021 HRMARS

summarized that overall Multidimensional Poverty Index (MPI) score whereas, there are 0.0029 or $.29 \%$ of the respondent are depriving together in the category of basic education, health and standard of living among lower income group in Selangor, Malaysia. Finally, the present study recommends policy considerations for the successful and effective operation of poverty alleviation programmes by providing the necessary guidelines to lower income group by increasing of income-generating activities, and proper education for the household's; and giving economic freedom of choice with necessary skill training.

\section{Acknowledgement}

The authors gratefully acknowledged the financial support for this research from the Grant Industry Semesta-2020 Grant No I/SEM-MBI/SS/2020/01

\section{References}

Abdul Rahman, M., Sani, N. S., Hamdan, R., Ali Othman, Z., \& Abu Bakar, A. (2021). A clustering approach to identify multidimensional poverty indicators for the bottom 40 percent group. PLOS ONE, 16(8), e0255312.

Abul, B. B., Chamhuri, S., Abdul, G. I., \& Islam, M. A. (2012). Microfinance and sustainable livelihood: a conceptual linkage of microfinancing approaches towards sustainable livelihood. American Journal of Environmental Sciences, 8(3), 328-333.

Ali, S., FerdausurRahman, M., Bhuiyan, A. B., \& Sina, A. (2014). Microfinancing impacts on socioeconomic development: an empirical study of Grameen Bank in Bangladesh. Advances in Environmental Biology, 554-563.

Azhar, N. A. Z. M., \& Mohd, S. (2020). Using asset index to reassess poverty in the Northern States of Malaysia: do the poor stay poor? International Journal of Social Economics.

Bhuiyan, A. B., Chamhuri, S., Ismail, A. G., \& Basri, T. (2013). Microfinance and Poverty Alleviation: A Conceptual Linkage of Microfinancing Approaches for Poverty Alleviation. Journal of Applied Sciences Research." Journal of Applied Sciences Research, 9(1), 17-21.

Bhuiyan, A. B., \& Hassan, A. (2013). Microcredit and sustainable livelihood: an empirical study of Islamic and conventional credit on the development of human capital of the borrowers in Bangladesh. Journal of Economic Cooperation and Development, 34(3), 101-128.

Bhuiyan, A. B., Siwar, C., Islam, R., \& Adhan, K. N. (2012). Greening Economics and Sustainable Livelihood and Socio-economic Well-being of the Low income Households in Malaysia. Research Journal of Environmental Sciences, 6(5), 156-168.

Chua, S. C., \& Oh, T. H. (2011). Green progress and prospect in Malaysia. Renewable and Sustainable Energy Reviews, 15(6), 2850-2861.

Gopal, P. S. (2018). Poverty measurement revisited from a multidimensional perspective among Universiti Sains Malaysia's B40 poor students. Geografia-Malaysian Journal of Society and Space, 14(4).

Haque, T., Siwar, C., Bhuiyan, A. B., \& Joarder, M. H. R. (2019). Contributions of Amanah Ikhtiar Malaysia (AIM) Microfinance to Economic Empowerment (EE) of Women Borrowers in Malaysia. Economics \& Sociology, 12(4), 241-256.

Haque, T., Siwar, C., Ghazali, R., \& Bhuiyan, A. B. (2018). The Microfinance Contributions on the Household Income of the Borrowers of Amanah Ikhtiar Malaysia (AIM) in Malaysia. Selangor Business Review, 3(1), 1-14. 
INTERNATIONAL JOURNAL OF ACADEMIC RESEARCH IN ACCOUNTING, FINANCE AND

\section{MANAGEMENT SCIENCES}

Vol. 11, No. 3, 2021, E-ISSN: $2225-8329$ @ 2021 HRMARS

Kronbak, L. G., \& Vestergaard, N. (2011). Towards a Green Economy: Pathways to Sustainable Development and Poverty Eradication: Fisheries Investing in natural capital. Retrieved from

Nair, S. (2010). Moving forward: Its poverty agenda challenges, dilemma and options for Malaysia.

Nair, S., \& Sagaran, S. (2015). Poverty in Malaysia - Institutions and Economies. Institutes and Economices, 7(3), 95-123.

Ravallion, M. (2020). Ethnic inequality and poverty in Malaysia since May 1969. Part 1: Inequality. World Development, 134, 105040.

Samsudin, H. B., \& Nadzrulizam, A. A. ( 2021). Relationship between B40 Household Income and Demographic Factors in Malaysia.

Shong, T. S., Abu Bakar, S. H., \& Islam, M. R. (2019). Poverty and delinquency: A qualitative study on selected juvenile offenders in Malaysia. International Social Work, 62(2), 965-979. doi:10.1177/0020872818756172

Vaziri, M., Acheampong, M., Downs, J., \& Majid, M. R. (2019). Poverty as a function of space: Understanding the spatial configuration of poverty in Malaysia for Sustainable Development Goal number one. GeoJournal, 84(5), 1317-1336. 